\title{
The Impact of the Development of American New Media on Citizens' Political Power and Life
}

\begin{abstract}
Yueming $\mathrm{Ni}^{1, *}$
${ }^{1}$ Hong Kong Metropolitan University, Hong Kong, 999077

*Corresponding author. Email: niyueming200826@gmail.com

ABSTRACT

The rapid development of new media in the 1990s had a significant impact on the lives of American citizens, and citizens' awareness of political power began to "awaken" unprecedentedly. The development of new technologies over the past decade has helped political consciousness reach its peak. However, what follows is the wanton use of new media by political leaders. "False news" and "post-truth era" are all the rage, showing a negative trend as a whole. It seriously affects citizens' ability to judge. Social media is a double-edged sword, but how to use it really needs us to think deeply. We are forced to hand over the initiative to the superstructure. It is time for American citizens to "regain" the initiative. The theme of this study will focus on "the development of new media and the life of American citizens", link it to "American political life", and further explain how "the development of new media" will affect citizens' political rights. This study refers to a large number of documents and integrates the thoughts of successful people in this field, such as business, politics and even social celebrities.
\end{abstract}

Keywords: New media, Political-media system, Post-truth society, The post PC World, American media system

\section{INTRODUCTION}

Political scientist-Bruce Bimber: "The exercise of power and the allocation of advantages and dominance in a democracy are related to technological change". Who controls, consumes, and distributes information depends to a large extent on who can best control digital technology. Social media has become an important intermediary for political and media participants to exert influence. The media is us. We have great interests and responsibilities in the world we create with the Internet. When he talks about the "global village", his view is not just that we will connect. He worries that we all know each other's affairs. We live in such a close world that we will lose a certain degree of privacy. [1] This study aims to learn from the use of political power in the development of American new media, or citizens' "political awakening" to resist "improper" new media.

\section{MAJOR CHANGES IN THE MEDIA SYSTEM}

Since the birth of new media in the late 1980s, the American media system has undergone significant changes. [2] Social media has become the main news source for millions of American citizens. We find that people's access to information has significantly shifted from traditional media (such as television and print newspapers) to online news and smartphone news applications. Moreover, under the influence of the general environment, the technological innovation brought by the Internet is comprehensively subverting various traditional industries and breaking the monopoly of traditional media. The era of new media has come, new communication carriers are emerging, the media function is no longer the exclusive interest of traditional media, and the traditional media represented by newspapers began to be weak to some extent, In 2004, some scholars in the United States also put forward the "theory of newspaper extinction" (there has even been a "wave of newspaper closures" in some parts of the United States). It can be said that as a product of the industrial age, the traditional media will go to the deep valley step by step in the information age, and an era will come to an end. [3] In addition, we found that the traditional hierarchy of media organizations is quietly being eroded. The political scandals that broke out in tabloid media began to appear on the front page of the New York Times, and the authenticity has been questioned. 
With the change of the times, the media has become a two-way contact movement in which all people participate. On the one hand, the low threshold of social media provides the public with more opportunities for political participation, reduces the distance between the public and decision-makers, and makes it possible to turn the democratic ideal into reality. The ability of social media to quickly amplify information through different media platforms enhances its ability to influence politics. It can be said that it has become a news media with a large audience. In particular, limited news is a stable source of political content. It also contributed to the success of social movements and political protests by promoting information and logistics facilities. On the other hand, our behavior of consuming media has created a new form of it - the social data layer, which reveals our behavior and makes us lose a certain degree of privacy. Everything can be measured, quantified, and stored. Website programmers can view the online consumption statistics of all their posts in real-time, analyze how to make more attractive content to readers, and even make an in-depth analysis of the audience's behavior, interest and emotion. In this way, we will be attracted by the temptation of the network and more social relations. In maximizing "social relations", we are always "connected" to an Internet supporting device. These can be smartphones, cars, sports bracelets, sensors, signals, and servers, which record a large amount of data of our daily life. The media follows us, and we are digitized. More and more data about our lives are almost permanently stored on the server, and can even be searched by others. We need to understand that we have entered the post PC World in the 21 st century. All devices and things are connected. Everything responds quickly in the "Internet of things era". This is a world that is always online and highly connected. It can be said that the Internet gives us unparalleled ability to create and express ourselves, but it also means that the responsibility borne on us will become great. We need to understand that we are the media. Although the saturated and overflowing information in the new media era will inundate us, and even we will have the emotion of "doubt and fatigue", we still need to keep a clear mind to distinguish complex situations. Not only that, but we also find that there are some problems in the differentiation of the media market. Although the development of technology gives us more choices in information, the "audience segmentation" will create discrete communities of special interests, resulting in our ability to hear many voices. In this seemingly open "new media" environment, there is still a fortress for more privileged members. Newer forms of communication will attract groups from higher socio-economic and educational levels, and "discussion" will be limited to their scope. In most cases, political and media elites still control the agenda of media forums. Although it improves the accuracy of information to a certain extent, this trend will stimulate the general public to go further and further in the process of public discussion and feedback. This is a question that we should deeply reflect on. Therefore, on the whole, on one hand, the Internet has widened the gap between "yes" and "no" political information and participation in the community, because newer forms of communication will attract audiences from higher socio-economic and educational groups to actively participate in political activities, but at the same time, most citizens without resources and skills cannot participate. [8]

\section{THE INTERSECTION OF NEW MEDIA AND POLITICAL POWER}

\subsection{The Political Role of Entertainment Platforms}

It is hard to imagine that entertainment platforms (such as talk shows and tabloids) played a prominent political role in the late 1980 s. This is because these entertainment platforms gave birth to "information entertainment". They blurred the boundary between news and entertainment and put sensational and scandal-driven stories and reports in front of hard news, which attracted audiences who are usually not interested in public affairs. This is the beginning of the impact of "new media" on democratic politics. [6] The early "new media" focused on the "entertainment" direction of narrative content and methods, which provided an excellent "platform" for political leaders and candidates to show their forms to the public. In the 1990s, the vigorous development of the Internet made the connection between "new media" and politics closer and more intense. Technological innovation enables the public to gain greater political influence, enable them to respond quickly to socially sensitive events, and allow them to communicate directly with political leaders and candidates. For example, they can provide original news, images, videos, and other political-related content. We need to understand that the whole process is a two-way input-output process. Politicians also use this channel to convey the political information they want to convey to citizens, to influence the opinions of voters. The development of technology has further expanded its political rights. Journalists have been playing a pivotal role in the political field before, but the development of the Internet and social media has transferred part of the control of information to political leaders and candidates. Politicians can now bypass journalists and make "emotional" connections directly with citizens. It can be said that "new political media" "Has changed the political-media system and redefined the role of journalists. Similarly, it also defines the way of election competition and citizens' participation in politics. Political leaders can not only use social media to control the direction of news, but also use these platforms to cultivate their political foundation; for the elite groups 
in the public, they can use social media to Speaking and communicating in public forums also had a great impact on politics. "5" However, at the same time, we find that the real populist potential of new media is gradually weakened due to the random evolution of new political media, gradually dominated by commercial interest groups and those groups that have occupied a privileged position in the political and news industries, and there are no guiding principles and objectives. The above-mentioned politicians and elites have strengthened their control over information, which makes the so-called At first, the public responded positively to more accessible communication channels, such as calling for political talk shows and online town hall meetings, but their enthusiasm will eventually be replaced by contradiction and cynicism (especially as the novelty of the first stage of new media gradually disappears).

In the past 10 years, social media has developed rapidly, in which the transformation of public loyalty to media to digital resources and the narrowing of the demographic differences of political social media have made politicians see the potential of these platforms. Here the author has to mention the political role of social media in American politics in 2008. [9] The social media strategy of Democratic presidential candidate Barack Obama in 2008 completely changed the election campaign by changing the political organizational structure. His campaign is characterized by a strong social movement of digital grass-roots mobilization. He and his team use the potential of social media networks, collaboration, and community construction to make personalized appeals to voters, and guide targeted information transmission with the help of data analysis, to cultivate their political foundation. A very interesting thing. One of Obama's campaign advisers is Facebook co-founder Chris Hughes. The campaign has enabled Hughes to establish a strong online image for Obama, including some websites such as YouTube, Facebook, and MySpace. [3] Therefore, since 2008, political parties and campaign organizations have been trying to guide voters to participate in elections through official websites and social media platforms, to "super manage" voters' digital participation. For example, these organizations will control voters' access to information through "micro-target information" according to users' data, political tendencies, and consumer preferences from their social media accounts, to imperceptibly affect their choices. Same. Social media also carries the interaction between users. Users often use social media to search for like-minded people and organizations, to increase their social contacts and further strengthen their personal and political labels. Everything is interconnected and influenced.

\subsection{The potential of social media}

Social media has great potential. Political leaders are more inclined to use social media to achieve political purposes, but at the same time, political leaders are increasingly pushing discourse and behavior to extremes. [10] This embodiment reached its peak during Trump's administration. Twitter and other social media quickly promote false information and prank information, which once became a flood. Alternative facts and false news are "good" cases at this stage. The typical feature of new media is that it can directly transmit information to individuals without the intervention of "intermediaries" (editors and institutional gatekeepers). Political leaders and candidates are directly linked to their voters. But this has increased the instability and unpredictability of the new media in the process of political communication. The content of the report can be completely fabricated, and social networks even help the proliferation of false information and pranks. We find that stories often spread through the Internet are novel and easy to resonate among readers. Even these false facts can enter the legal news network platform and confuse people's audio-visual. The proliferation of misinformation hinders responsible decision-making. Thus, the possibility of political leaders making negative use of the power of social media has been realized. This undermines citizens' democratic governance right to access high-quality decision-making information. Trump's "reckless" use of Twitter enabled him to communicate directly with the public, manage his political allies and critics, and control the news agenda. This is a very typical example. It is not difficult to find that Trump's messages are always conflicting, confusing, and unclear, but he often uses a tone of trying to sell goods, helps users explain them with preconceived ideas, and helps trump cultivate a sense of trust and familiarity among his loyal fans. During Trump's administration, the concept of "post-truth society" was all the rage. Here, the so-called "post-truth" refers to the situation where truth and logic are ignored in the process of information dissemination and emotion incites the dominant public opinion. From voting to crowdfunding fraud to virus marketing. The truth is dismembered, distorted, and covered up by the messenger. Truth and logic are ignored in the process of information dissemination. Emotion incites dominant public opinion. Vague statements with core authenticity but inconsistent with the facts have become the currency of politicians, business executives, and other power brokers during the trump period. [11] Moreover, in the eyes of the "watchdog" - journalists, where politics is involved, the only bad news is worth reporting. People rarely hear stories about how some government agencies work well or admirable civil servants, which are "hidden" by journalists because they believe that this news does not have good economic value. Under the influence of the above factors and environment, "false 
news" is a typical product of this period. (fake news is an imitation and satire of the news. In the 2016 presidential election, this concept was added to fictional stories to make the reported articles look like real news content, to further confuse the audience. Fake news even spread wantonly on websites with legitimate news platforms and blogs, making extreme use of people's understanding of political leaders, political parties and organizations And mainstream news media).

False news helps the government confuse basic facts with fictitious facts. "Post-truth society" disgusts and suffocates citizens. Therefore, CNN even launched the "fact first" campaign, hoping to break the deadlock and respond to the "continuous attack" of politics. In the dissemination of local information, "news desert" and "forced reading" are prevalent. The wrong information is often regarded as a fact. There is no responsible local news agency in the community where people live to provide information to residents and fight back against false reports. The wrong information is disseminated through people's social networks. It is worth mentioning that hosts all over the country often recite similar scripts and listen to the "command" of the political party. According to the research, local news stories affect the opinions of residents and largely affect the decision-making of community leaders. We may often ignore the importance of providing information and forming opinions for residents in small towns and suburban communities, but this is indeed a serious problem that cannot be ignored. "News desert" concentrates the ownership of media in the hands of large companies, which further destroys the real local news. The media "echo room" has exacerbated political polarization. People often choose the source of news and information according to the so-called affinity of politics. Social media has accelerated the development of the media "echo room". Although the media "echo room" helps people reach out to like-minded people and share information, it potentially isolates people with different views and reduces the diversity of "voices". [4]

\section{CONCLUSION}

In the new media era, the boundaries of different types of information are becoming more and more blurred, and there is even a trend of "blending". There are fewer and fewer professional media editors who use news principles and standards related to public interests to regulate information flow. Editors no longer focus on news value, but more tend to focus on how to attract users to pay attention to their content. The content of political news and information is more and more entertainment-oriented, and the overall tone is in a negative state. In addition, political content no longer performs the public service function of informing citizens. It has become a social media product to promote consumers to buy. The mode of news reporting by news media is consistent with the main entertainment news framework and emphasizes political discord, blasphemy, and scandal. It is often presented in a fragmented way and rarely contains some substantive information or background. Now, when we look at the whole news industry, we find that the negative characteristics and entertainment focus of political news weaken the significance of news transmission. In addition, the political information of more detailed and substantive political views is often directed to the more well-educated elite audience. Moreover, the news is also insider-oriented. The current overall news environment will undoubtedly reduce citizens' confidence in government officials and political institutions and the democratic political process. But generally speaking, the new media environment is dynamic and continues to develop in novel and sometimes unexpected ways, which has a significant impact on democratic governance and politics. New media not only expands the traditional role of the press in a democratic society but also weakens its role from another point of view. However, it is undeniable that the new media has fundamentally changed the operation mode of government institutions, the communication mode of political leaders, the mode of election competition, and citizen participation. It is hoped that this document can provide a reference for the relationship between "new media" and politics and life in China.

\section{AUTHORS' CONTRIBUTIONS} Ni.

This paper is independently completed by Yueming

\section{ACKNOWLEDGMENTS}

During the creation of the thesis, I am very grateful to my professor (Prof. Bernadett Wegenstein, Johns Hopkins University) for the inspiration brought to me by my course narrative form and communication in the new media era. In addition, I am grateful to my parents for their spiritual support and encouragement.

\section{REFERENCES}

[1] Lars Willnat and David H. Weaver. The American Journalist in the Digital Age: Key Findings. 2014. Bloomington, IN: School of Journalism, Indiana University.

[2] Tim Groeling and Matthew A. Baum. Crossing the Water's Edge: Elite Rhetoric, Media Coverage, and the Rally-Round-the-Flag Phenomenon [J] Journal of Politics 70, 2008. No. 4: 1065-1085.

[3] Anthony R. Fellow. American Media History [J] C) 2022, p. 544.

[4] Pew Research Center, Facebook and Twitter-New but Limited Parts of the Local News System, 5 
March 2015.

https://www.pewresearch.org/journalism/2015/03/0 5/facebook-and-twitter-new-but-limited-parts-of-th e-local-news-system/

[5] FDR: A Voice of Hope, September 10, 2015. http://www.history.com/topics/fireside-chats

[6] Shanto Iyengar. Media Politics: A Citizen's Guide, 3rd ed. New York: W.W. Norton. 2016. http://pcl.stanford.edu/common/docs /research/iyengar/2007/mp-excerpt.pdf

[7] Matthew A. Baum and Samuel Kernell. Has Cable Ended the Golden Age of Presidential Television? [J] The American Political Science Review 93, 1999.No. 1: 99-114.

[8] Number of Viewers of the State of the Union Addresses from 1993 to 2015 (in millions), August 28 , 2015 , http://www.statista.com/statistics/252425/state-of-t he-union-address-viewer-numbers

[9] Jeff Zeleny, Lose the BlackBerry? Yes He Can, Maybe, New York Times, 15 November, 2008. https://www.nytimes.com/2008/11/16/us/poli tics/16blackberry.html

[10] Pew Research Center, Public Knowledge of Current Affairs Little Changed by News and Information Revolutions, 15 April 2007; Fairleigh Dickinson University, What You Know Depends on What You Watch: Current Events Knowledge across Popular News Sources, 3 May 2012, http://publicmind.fdu.edu/2012/confirmed/.

[11] Markus Prior. Any Good News in Soft News? The Impact of Soft News Preference on Political Knowledge [J] Political Communication 20, 2003. No. 2: 149-171. 